\title{
TRENDS IN SCHOOL ENROLLMENT AND GRADUATION: THE EXPERIENCE OF EDUCATIONAL MANAGEMENT STUDENTS IN THE GRADUATE SCHOOL
}

\author{
Oleh \\ Noemi B. Zulieta ${ }^{1}$, I Ketut Sudarsana ${ }^{2}$, Gilbert S. Arrieta ${ }^{3}$, Inero V. Ancho ${ }^{4}$ \\ ${ }^{14}$ Philippine Normal University, Manila, Philippines \\ ${ }^{2}$ Universitas Hindu Negeri I Gusti Bagus Sugriwa Denpasar, Bali, Indonesia \\ ${ }^{3}$ Don Bosco Techincal School, Makati City, Philippines \\ iketutsudarsana@ihdn.ac.id, ${ }^{4}$ ancho.iv@pnu.edu
}

diterima 12 Desember 2019, direvisi 17 Januari 2020, diterbitkan 29 Pebruari 2020

\begin{abstract}
Abstrak
Studi ini melihat tren dalam pendaftaran dan kelulusan siswa educational management (EdM) di sebuah lembaga pendidikan guru di Manila. Mempertimbangkan tantangan mahasiswa pascasarjana yang juga guru atau pengawas di sekolah masing-masing, mungkin sulit bagi mereka untuk mengelola pekerjaan dan studi secara bersamaan yang dapat mengarah pada pengunduran diri dari kursus atau tidak berhasil menyelesaikan studi master dan doktor mereka. Berdasarkan data, ditemukan bahwa pendaftaran di tingkat master menurun tetapi stabil di tingkat doktor dalam enam tahun akademik terakhir (2013-2014 hingga 2018-2019). Secara khusus, ada penurunan yang signifikan dalam pendaftaran musim panas di kedua level. Ada lebih banyak siswa perempuan daripada siswa laki-laki yang mendaftar dalam program ini. Dalam hal penyelesaian yang berhasil, jumlah lulusan secara signifikan rendah dan lebih banyak perempuan daripada siswa laki-laki yang lulus.
\end{abstract}

\section{Kata Kunci: Pendaftaran, Kelulusan, Manajemen Pendidikan, Filipina}

\begin{abstract}
The study looked into the trends in the enrollment and graduation of educational management (EdM) students in a teacher education institution in Manila. Considering the challenges of graduate students who are also teachers or supervisors in their respective schools, it may be difficult for them to manage work and studies simultaneously which may lead to dropping from the course or unsuccessfully completing their masters and doctoral studies. Based on the data, it found out that enrollment in the master's level decreased but is stable in the doctoral level in the last six academic years (2013-2014 to 20182019). In particular, there is a significant decrease in summer enrollment in both levels. There were more female than male students who enrolled in the
\end{abstract}


program. In terms of successful completion, the number of graduates is significantly low and more female than male students graduated.

\section{Keywords: Enrolment, Graduation, Educational Management, Philippines}

\section{INTRODUCTION}

Enrolling in a graduate course entails sacrifices, challenges, and opportunities. Earning a graduate degree is considered to be an achievement, given the nature of work demands and academic pressure. In the context of education where attending graduate school appears to be a prerequisite and one of the avenues for work promotion and professional growth, teaching and nonteaching staff pursue higher academic degree while performing their full-time jobs at school or any education-related institutions. "The type of education to pursue and how much to pursue" are a few concerns of a population that has becoming more and more educated (Altonji, Arcidiacono, Maurel, 2016). Teaching and mentoring in the graduate school should be able to meet students' non-academic needs in order to achieve a more pleasant experience (Ding, et al., 2017). According to Baum and Steele (2017), seeking pursuing advance degree has gained "momentum" in the recent years, considering it to be "the new bachelor's degree".

The decision to enroll in a graduate program goes with assuming gigantic and additional roles. English and Umbach (2016) were able to identify three phases when it comes to graduate school choice: aspiration, application, and enrolment. To some professionals, going back to school in the midst of workload and personal affairs would mean juggling numerous responsibilities. According to Miller and Orsillo (2020), for most students, the shift to graduate school is considered a time of "dramatic change". The usual time allotted for attending to personal and professional errands would now be occupied by lectures and writing academic papers for class requirements. Individual factors related to student attrition refer to demographics, skills and abilities, goals and expectation, external commitments, and academic history (Allen et al., 2019). Students in the graduate level experience competition, personal stressors, financial issues and other concerns (Jazaieri, 2017).

In the context of teaching profession, teachers are encouraged to attend graduate school for a number of reasons. It is imperative that pursuing higher education entails increases one's calibre as a professional, strengthening specs which eventually lead to promotion and higher leverage at work. According to (Levin, Belfield, Muennig, \& Rouse, 2007), higher degree leads to "stronger career opportunities, greater financial stability, and positive health outcomes." Teachers are also exposed to trends and up-to-date practices in teaching and learning once they attend graduate school. The professional training and interaction with other practitioners also lead to healthy and favourable gains for the teacher. To some, pursuing higher studies is one way of realizing growth and advancement. It is believed that the challenges that come with full-time work and higher studies provide avenues to maximize one's potentials, especially in the field of research.

In the Philippines, educational management (EdM) is one area of specialization in the graduate studies that is frequently pursued by teachers. It goes with the assumption that school leadership posts (principals, school head, school director, coordinator, and others) are being filled in by those with higher degrees, thus, EdM becomes a program with stable number of students, if not the most popular one. Hess and Kelly (2007) call for an approach to educational leadership training which "reflect the content of instruction and what approaches to instruction or assessment are employed in the course of principal 
preparation," thus an evident need to revisit educational leadership and management programs. A study by Jackson and Kelly (2002) revealed that despite concerns regarding the quality of educational administration programs, "innovative and exceptional" program features still exist.

EdM as a program of study deals with the theoretical and practical approaches to leadership and management. Coursework includes areas related to curriculum, finance, legislation, ethics, organizational behaviour and development, human resource, and others. Completion of the required coursework would qualify the student to take the Comprehensive Examinations, which once hurdled serves as the gateway to writing of the thesis or dissertation project.

This study is an attempt to look at the trends of student enrollment and graduation in a Master of Arts in Education and Doctor of Philosophy programs with specialization in Educational Management (Educational Leadership and Management from 2017 following curricular revisions) in a teacher education institution in Manila, Philippines. The research is part of a larger study and this paper solely presents the plight of students who decide to enroll in the program, and those who successfully graduated.

How many enrolled? How many graduated? What is the success rate? These questions serve as starting points of the inquiry in the hope of establishing a more concrete and evidence-based approach to successful completion of $\mathrm{MA}$ and $\mathrm{PhD}$ programs in the context of educational leadership and management. Also, this paper attempts to provide implications to teacher education in particular, and graduate education in general.

It is indeed a challenge to retain and increase graduate rates in the graduate school especially when students are tied with workload and other personal affairs, along with other issues they confront. The investment being put into education both by the national government and the students themselves is realized once success rate in terms of enrolment and graduation is met.

\section{METHOD}

This study purely involves analysis of available data from the Office of the University Registrar of a teacher education institution in Manila, Philippines. A format letter was sent requesting for enrolment and graduation rates for $\mathrm{MA}$ and $\mathrm{PhD} \mathrm{EdM}$ programs, which was eventually approved and granted. Apparently, institutional digital archiving started in 2013, thus the provided data covers the years 2013 - 2019. The research poses no ethical threats to human beings and proper and ethical treatment of data was observed during the course of the research. Quantitative data provided to the researches were used solely for the purpose of this study.

\section{RESULTS AND DISCUSSION}

The Educational Management Program is one of the graduate school programs with the most number of enrollees both in the master's and doctoral levels. Table 1 shows that the average registered enrollment in the Master of Arts in EdM is 115.35 from academic year 2013 - 2019. On the other hand, Table 2 shows that the average registered enrollment in the Ph.D. in EdM is 43.26.

The following discusses the results, analysis and interpretation of the enrollment data in graduate school in a teacher education institution particularly the educational management in the master's and doctoral levels :

\section{Decrease in Enrollment in the Masters Level}

In the master's level, Table 1 shows that school year 2013-2014 has the highest average of enrollment with 134.3. However, since 2014-2015, the enrollment started to decrease slowly until 2018-2019 with an average of 82.5, the lowest average in the six school years. The decrease in enrollment from $2015-2016$ to $2016-2017$ is 12 , from 2016-2017 to $2017-2018$ is 19.75 , and from 2017-2018 to $2018-2019$ is 15 . The total decrease in enrollment in the last three school years is 46.75 which can be considered significant. It suggests that there are various factors that may have contributed 
to the decrease in enrollment like verticallyarticulated academic qualifications for teachers and professors as mandated by the Department of Education and Commission on Higher Education and less interest in school leadership. In its Memorandum Circular No. 22 s. 2016, the Civil Service Commission stated that the education requirement for faculty positions in State Universities and Colleges, and Local Universities and Colleges is a master's degree in the area of specialization or its allied courses based on CHED Memorandum Orders on the policies, standards and guidelines.

In the doctoral level, Table 2 shows that the average registered enrollment is 43.26. With the exception of school year 2014-2015 where the enrollment dropped to 35.33 , the enrollment remains stable. Ironically, the enrollment in graduate programs in the United States is increasing. The National Center for Education Statistics (2019) in the United States reported that in fall 2017, some 3.0 million students were enrolled in postbaccalaureate degree programs. Postbaccalaureate degree programs include master's and doctoral programs, as well as professional doctoral programs such as law, medicine, and dentistry. Total postbaccalaureate enrollment increased by 36 percent between 2000 and 2010 (from 2.2 million to 2.9 million students) and was 2 percent higher in 2017 than in 2010 (3.0 million vs. 2.9 million students). Between 2017 and 2028, post-baccalaureate enrollment is projected to increase by 3 percent (from 3.0 million to 3.1 million students).

\section{Stable Enrollment In The Doctoral Level}

In the doctoral level, Table 2 shows that the average registered enrollment is 43.26. With the exception of school year 2014-2015 where the enrollment dropped to 35.33 , the enrollment remains stable. It suggests that current and future school leaders are taking doctoral studies to continue enhancing their knowledge and skills in educational leadership and management. The data is consistent with the CHED report on enrollment in the doctoral level from academic year 2015-2016 to 2018-2019. The enrollment in the doctoral level increased during the aforementioned academic years with 22,470 doctoral students in 2015-2016, 23,827 in $2016-2017,26,961$ in $2017-2018$, and 29,831 in 2018-2019.

\section{Decrease in Summer Enrollment}

Another notable finding is the decrease in enrollment in the MA program during summer classes. Usually, the summer term is the best time for teachers to take graduate studies for they are free from work. Table 1 shows that in school year 2013-2014, 20142015, and 2015-2016, the summer enrollment were 80, 71, and 62 respectively. There is a decrease in enrollment during the aforementioned school years but it is not significant. However, the next three school years, 2016-2017, 2017-2018, and 20182019 showed a significant decrease in enrollment with only 30,25 , and 13 recorded registered enrollment during summer. From as high as 80 registered summer enrollment in school year 2013-2014, it dropped to 13 in 2018-2019 which is considered very high. The decrease of summer enrollment particularly in the last three years can be attributed to the shift from the semestral to trimester schedule in the university and the shift of the opening of school year from June to August in 2015 by many private schools, colleges, and universities.

The university started following the trimester schedule in academic year 20152016. The next academic year saw the drop in summer enrollment. Having three terms from June to March, graduate students may have opted to take a rest after a year filled with workload in their respective schools and graduate school requirements. The three terms may be enough for their academic requirements and a breather during summer would be a necessity to prepare for the next academic year.

The shift of the opening of the academic year may have been a factor in the decrease in summer enrollment. Since public 
schools and most state universities and colleges did not move the opening of the school year to June, summer classes in the university were held in April and May when many teachers in the private schools were still having classes. They could not enroll because of the conflict in their work schedule. In the university, summer classes are held every day, Monday to Friday. The regular term classes were held mostly on Saturdays with some classes during weekdays, after school hours.

The decrease in enrollment continued because many schools including some state universities and colleges followed the shift in the opening of school year in the last two years. In the report of GMA Newsonline (2014), stated that Philippine universities will no longer be out of step with the rest of the world. The leading Philippine colleges and universities will begin the next school year in August in order to align them with foreign counterparts. Most universities in the world begin the school year in August, September, or October, while the Philippines has stuck to its June to March calendar. The Philippines is also the only member of the Association of Southeast Asian Nations (ASEAN) still starting its academic year in June, since Thailand adopted the SeptemberMay calendar in 2011.

With ASEAN integration in 2015 creating new opportunities to internationalize their campuses and the K-12 education system severely affecting college enrollment in 2016 Philippine institutions are feeling the pressure to shift their academic calendars. Incidentally, the Commission on Higher Education (CHED) issued a memorandum dated April 5, 2019 which states that "Pursuant to the pertinent provisions of RA 7722, otherwise known as "Higher Education Act of 1994" and CEB Resolution No. 1422019, all State Universities (SUCs) and Local Universities and Colleges (LUCs) are enjoined to synchronize its respective Academic Year (AY) to a Fiscal Year (FY) starting FY 2019 and to ensure that starting FY 2020, all SUCs and LUCs have synchronized their academic year to a fiscal year." This recommendation may lead to the increase in enrollment during summer though some may opt to take a vacation due to tiredness during the school year when teachers work and study at the same time.

\section{More Female than Male Students}

Both master's and doctoral levels show that there are more female than male students who have been enrolling in the program both for the master's and doctoral levels. Table 1 shows that in the master's program, the average enrollment of female students is 86.85 compared to 30 for male students. On the other hand, Table 2 shows that in the doctoral program, the average enrollment of female students is 29.77 while the male students is 13.48 . It can be gleaned from the data that more female students are interested to take leadership roles in schools.

Insofar as teaching career is concerned, statistics will show that there are more female teachers than male teachers. Hence, it is expected that there will be more female school heads than male. In the study of Hill et al (2016) on the trends in public and private school principal demographics and qualifications: $1987-88$ to $2011-12$ in the United States, it revealed that over the 24year span shown in figure 1 , the percentage of female principals increased in public schools, from 25 percent of all principals in 1987-88 to 52 percent in 2011-12. However, private schools had significantly greater percentages of female principals than did their public school counterparts in all years except 2007-08. In private schools, the proportion of female principals was 52 percent in school year 1987-88 and 55 percent in school year 2011-12.

In the Philippines, there are more female than male teachers. The National Center for Education Statistics (2019) in the United States also reported that in fall 2017, female students made up 59 percent of total post baccalaureate enrollment (1.8 million students), and male students made up 41 percent (1.2 million students). Between 2000 and 2010, female enrollment increased by 42 percent, a faster increase than that observed 
for male enrollment (28 percent). In addition, female enrollment was 3 percent higher in 2017 than in 2010 (1.8 million vs. 1.7 million students), whereas male enrollment was 1 percent higher (1.22 million vs. 1.21 million students). Between 2017 and 2018, however, male enrollment is projected to increase by 3 percent (from 1.2 million to 1.3 million students) and female enrollment is projected to increase by 3 percent (from 1.79 million to 1.84 million students). In the
Philippines, the Commission on Higher Education (CHED) reported that in academic year 2017-2018, there were 214,540 students who enrolled in the master's level with 147,662 are female and 66,878 are male. In the doctoral level, there were 26,961 students who enrolled with 16,389 are female and 10,572 are male. Consistent with the data found in Table 1, there are more female than male students pursuing graduate studies.

Table 1

Enrolment Data for Master of Arts in Educational Leadership and Management 2013 - 2019

\begin{tabular}{|c|c|c|c|c|}
\hline \multirow[t]{2}{*}{ SCHOOL YEAR } & \multirow[t]{2}{*}{ SEMESTER/TERM } & \multicolumn{2}{|c|}{$\begin{array}{l}\text { Master of Arts in } \\
\text { Education }\end{array}$} & \multirow[t]{2}{*}{ Total } \\
\hline & & MALE & FEMALE & \\
\hline \multirow[b]{3}{*}{$2013-2014$} & 1st Semester & 34 & 140 & \\
\hline & 2nd Semester & 28 & 121 & \\
\hline & Summer & 25 & 55 & \\
\hline TOTAL & & 87 & 316 & 403 \\
\hline \multirow[t]{2}{*}{ AVERAGE } & & 29 & 105.3 & 134.3 \\
\hline & & $22 \%$ & $78.40 \%$ & \\
\hline \multirow{3}{*}{$2014-2015$} & 1st Semester & 61 & 103 & \\
\hline & 2nd Semester & 42 & 117 & \\
\hline & Summer & 14 & 57 & \\
\hline TOTAL & & 117 & 277 & 394 \\
\hline \multirow[t]{2}{*}{ AVERAGE } & & 39 & 92.33 & 131.33 \\
\hline & & $29.69 \%$ & $70.30 \%$ & \\
\hline \multirow{4}{*}{$2015-2016$} & Term 1 & 42 & 118 & \\
\hline & Term 2 & 39 & 114 & \\
\hline & Term 3 & 22 & 120 & \\
\hline & Summer & 8 & 54 & \\
\hline TOTAL & & 111 & 406 & 517 \\
\hline \multirow[t]{2}{*}{ AVERAGE } & & 27.75 & 101.5 & 129.25 \\
\hline & & $21.47 \%$ & $78.52 \%$ & \\
\hline \multirow{4}{*}{$2016-2017$} & Term 1 & 44 & 128 & \\
\hline & Term 2 & 31 & 103 & \\
\hline & Term 3 & 27 & 106 & \\
\hline & Summer & 7 & 23 & \\
\hline TOTAL & & 109 & 360 & 469 \\
\hline \multirow[t]{2}{*}{ AVERAGE } & & 36.3 & 90 & 117.25 \\
\hline & & $30.95 \%$ & $76.75 \%$ & \\
\hline $2017-2018$ & Term 1 & 36 & 116 & \\
\hline
\end{tabular}




\begin{tabular}{|c|c|c|c|c|}
\hline & Term 2 & 30 & 82 & \\
\hline & Term 3 & 32 & 69 & \\
\hline & Summer & 9 & 16 & \\
\hline TOTAL & & 107 & 283 & 390 \\
\hline AVERAGE & & 26.75 & 70.75 & 97.5 \\
\hline & & $27.43 \%$ & $72.56 \%$ & \\
\hline & Term 1 & 26 & 76 & \\
\hline $2018-2019$ & Term 2 & 23 & 73 & \\
\hline & Term 3 & 32 & 87 & \\
\hline & Summer & 4 & 9 & \\
\hline TOTAL & & 85 & 245 & 330 \\
\hline AVERAGE & & 21.25 & 61.25 & 82.5 \\
\hline & & $25.75 \%$ & $74.24 \%$ & \\
\hline $\begin{array}{r}\text { AVERAGE E } \\
\text { SCH }\end{array}$ & $\begin{array}{l}\text { NT IN SIX } \\
\text { S }\end{array}$ & 30 & 86.85 & 115.3 \\
\hline & & $26.01 \%$ & $75.32 \%$ & \\
\hline
\end{tabular}

Table 2

Enrolment Data for Doctor of Philosophy in Educational Leadership and Management 2013 $-2019$

\begin{tabular}{|c|c|c|c|c|}
\hline \multirow{2}{*}{ SCHOOL YEAR } & \multirow{2}{*}{$\begin{array}{c}\text { SEMESTER/ } \\
\text { TERM }\end{array}$} & \multicolumn{2}{|c|}{ Doctor of Philosophy } & \multirow{2}{*}{ Tota } \\
\hline & & MALE & FEMALE & \\
\hline \multirow{3}{*}{$2013-2014$} & 1st Semester & 17 & 62 & \\
\hline & 2nd Semester & 9 & 39 & \\
\hline & Summer & 4 & 10 & \\
\hline TOTAL & & 30 & 111 & 141 \\
\hline \multirow[t]{2}{*}{ AVERAGE } & & 10 & 37 & 47 \\
\hline & & $21.27 \%$ & $78.72 \%$ & \\
\hline \multirow{3}{*}{$2014-2015$} & 1st Semester & 11 & 30 & \\
\hline & 2nd Semester & 7 & 32 & \\
\hline & Summer & 8 & 18 & \\
\hline TOTAL & & 26 & 80 & 106 \\
\hline \multirow[t]{2}{*}{ AVERAGE } & & 8.66 & 26.66 & 35.33 \\
\hline & & $24.51 \%$ & $75.45 \%$ & \\
\hline \multirow{4}{*}{$2015-2016$} & Term 1 & 18 & 41 & \\
\hline & Term 2 & 16 & 35 & \\
\hline & Term 3 & 14 & 36 & \\
\hline & Summer & 4 & 11 & \\
\hline TOTAL & & 52 & 123 & 175 \\
\hline \multirow[t]{2}{*}{ AVERAGE } & & 13 & 30.75 & 43.75 \\
\hline & & $29.71 \%$ & $70.28 \%$ & \\
\hline
\end{tabular}




\begin{tabular}{|c|c|c|c|c|}
\hline \multirow{4}{*}{$2016-2017$} & Term 1 & 17 & 31 & \\
\hline & Term 2 & 17 & 28 & \\
\hline & Term 3 & 21 & 37 & \\
\hline & Summer & 12 & 17 & \\
\hline TOTAL & & 67 & 113 & 180 \\
\hline \multirow[t]{2}{*}{ AVERAGE } & & 16.75 & 28.25 & 45 \\
\hline & & $37.22 \%$ & 62.77 & \\
\hline \multirow{4}{*}{$2017-2018$} & Term 1 & 22 & 33 & \\
\hline & Term 2 & 18 & 29 & \\
\hline & Term 3 & 16 & 29 & \\
\hline & Summer & 6 & 18 & \\
\hline TOTAL & & 62 & 109 & 171 \\
\hline \multirow[t]{2}{*}{ AVERAGE } & & 15.5 & 27.25 & 42.75 \\
\hline & & $36.25 \%$ & $63.74 \%$ & \\
\hline \multirow{4}{*}{$2018-2019$} & Term 1 & 18 & 36 & \\
\hline & Term 2 & 17 & 36 & \\
\hline & Term 3 & 22 & 35 & \\
\hline & Summer & 11 & 8 & \\
\hline TOTAL & & 68 & 115 & 183 \\
\hline \multirow[t]{2}{*}{ AVERAGE } & & 17 & 28.75 & 45.75 \\
\hline & & 37.15 & $62.84 \%$ & \\
\hline \multirow{2}{*}{\multicolumn{2}{|c|}{$\begin{array}{c}\text { AVERAGE ENROLLMENT IN SIX } \\
\text { SCHOOL YEARS }\end{array}$}} & 30 & 86.85 & 115.3 \\
\hline & & $26.01 \%$ & $75.32 \%$ & \\
\hline
\end{tabular}

Few Graduates in Master's and Doctoral Levels

In terms of the number of graduates, Table 3 shows that the master's program has produced 43 graduates in the last six years with an average of 7.16 every school year. The number of graduates is only $6.20 \%$ in contrast with the average enrollment which is 115.35. This can be considered low. Moreover, the data do not say that the graduates entered the program in last six school years. A significant number of them may have started earlier than 2013-2014. The residency period for master's students is four years with an extension of two years. The data may indicate the lack of commitment of the students including serious issues and concerns related to the policies and processes in the graduate programs. The attrition rate can be considered. In the report of CHED from academic year 2015-2016 to 2017-2018, the average number of graduates is $29,876.33$ which is $15.64 \%$ against the average enrollment $(190,944.66)$. It can be gleaned that the attrition rate is significantly high.

Table 3 also shows that the doctoral program has produced 24 graduates in the last six years with an average of 4 graduates every school year. The number of graduates is $9.24 \%$ in contrast with the average enrollment which is 43.26. This is still considered low though it is higher than the graduates in the master's level. The data do not indicate that the graduates entered the program in the last six years. Most of them may have entered the program earlier than 2013-2014. The residency period for doctoral students is six years with an extension of two years. The data may indicate that there may be more doctoral students who are 
committed to finishing the program. However, the data suggest that there may be issues and concerns related to the policies and processes in the graduate programs. The Council of Graduate Schools (2016) produced a study on the $\mathrm{PhD}$ completion and attrition. The study looked at 49,000 students attending 30 institutions in 54 disciplines comprising 330 programs.

Astonishingly, the completion rate ten years after students begin their doctoral program remains low at $56.6 \%$. It added that growth in doctoral degree production was stronger between Fall 2013 and Fall 2018 $(1.9 \%)$ and over the ten-year period between Fall 2008 and Fall 2018 (3.6\%) than the growth in master's degree. The larger fiveand ten-year annual percentage changes of doctoral degree production was partly because the base rates of doctoral degrees awarded were lower. Ironically, CHED reported that the average number of graduates from academic year 2015-2016 to $2017-2018$ is $3,386.3$ which is $13.86 \%$ against the average enrollment which is $24,419.33$. The number of graduates in the doctoral level is significantly low.

\section{More Female than Male Graduates}

Since there are more female than male graduate students who have enrolled in the program both in the master's and doctoral levels, it is expected that there will be more female students who will graduate. Table 3 shows that 27 female students who graduated in the master's level compared to male students with 16 graduates. In the doctoral level, there were 15 female students and 9 male students who graduated. Looking closely at the data, it is consistent with various statistical reports. The 2018 report of the Council for Graduate Schools showed that completion rates for women enrolled in STEM master's programs were higher than those of men at the two-, three-, and fouryear periods. In contrast, completion rates for women enrolled in MBA master's programs were lower than those of men during the same time period. In the report of the Commission on Higher Education (CHED) in the Philippines for academic year 20172018 , it shows that there were more women than men who graduated in the master's and doctoral levels. In the master's program, there were 22,728 female graduates and 10,807 male graduates. There were 2,375 female graduates and 1,316 male graduates in the doctoral level.

\section{More Graduates in the Doctoral than Masters Level}

The data found on Table 3 that there are 43 graduates in the masters level and 24 in the doctoral level. Though there are more masters than doctoral students who graduated in the last six academic years, it can be drawn statistically from the data that there are more graduates in the doctoral level compared with the masters level. Based on the average number of enrollment, 9.24\% graduated in the doctoral level while $6.20 \%$ graduated in the masters level. Ironically, based on CHED report, the average number of graduates in the masters level and doctoral level from 2015-2016 to 2017-2018 is $29,876.33$ and $3,386.3$. This is $15.64 \%$ and $13.86 \%$ against the average enrollment in the aforementioned academic years.

Table 3

Graduation data for Master of Arts and Doctor of Philosophy in Educational Leadership and Management 2013 - 2019

\begin{tabular}{|c|c|c|c|c|}
\hline \multirow{2}{*}{ SCHOOL YEAR } & \multicolumn{2}{|c|}{ Master of Arts } & \multicolumn{2}{c|}{$\begin{array}{c}\text { Doctor of } \\
\text { Philosophy }\end{array}$} \\
\cline { 2 - 5 } & MALE & FEMALE & MALE & FEMALE \\
\hline $\mathbf{2 0 1 3}-\mathbf{2 0 1 4}$ & 0 & 5 & 2 & 2 \\
\hline $\mathbf{2 0 1 4}-\mathbf{2 0 1 5}$ & 6 & 3 & 1 & 6 \\
\hline $\mathbf{2 0 1 5}-\mathbf{2 0 1 6}$ & 4 & 4 & 3 & 2 \\
\hline
\end{tabular}




\begin{tabular}{|c|c|c|c|c|}
\hline 20162017 & 3 & 6 & 1 & 1 \\
\hline $2017-2018$ & 2 & 2 & 0 & 4 \\
\hline $2018-2019$ & 1 & 7 & 2 & 0 \\
\hline TOTAL & 16 & 27 & 9 & 15 \\
\hline & \multicolumn{2}{|c|}{43} & \multicolumn{2}{|c|}{24} \\
\hline $\begin{array}{l}\text { AVERAGE GRADUATES PER SCHOOL } \\
\text { YEAR }\end{array}$ & \multicolumn{2}{|c|}{7.16} & \multicolumn{2}{|c|}{4} \\
\hline AGAINST AVERAGE ENROLLEES & \multicolumn{2}{|c|}{$6.20 \%$} & \multicolumn{2}{|c|}{$9.24 \%$} \\
\hline $\begin{array}{l}\text { AVERAGE ENROLLEES PER SCHOOL } \\
\text { YEAR }\end{array}$ & \multicolumn{2}{|c|}{115.3} & \multicolumn{2}{|c|}{43.26} \\
\hline
\end{tabular}

\section{CONCLUSIONS}

This study found out that the enrollment in the masters level has significantly decreased but has remained stable in the doctoral level from academic year 2013-2014 to 2018-2019. In both masters and doctoral levels, summer enrollment decreased most especially in the last three school years which can be attributed to the shifting from semestral to trimester schedule of the university and the shift of academic year which both started in 2015. It also found out that there are more female than male students who enrolled in the masters and doctoral levels.

In terms of graduates in the program, the number of graduates in both levels is significantly low. Statistically, there are more graduates in the doctoral than the masters level. Looking into the number of graduates based on gender, there are more female than male graduates which is congruent with the enrollment data.

Based on the findings of the study, it can be concluded that :

1. more female teachers are inclined to take school leadership roles;

2. the decrease in enrollment in the educational management program is an issue that should be addressed immediately;

3. graduate students opt to take a rest during summer instead of enrolling in consideration of the demands of their work and graduate studies;

4. graduate students need more commitment and grit in completing the degree;
5. the significantly low number of graduates will require a careful review on the graduate school programs, policies and procedures;

\section{REFERENCES}

Allen, H., Lilly, F., Beck, K., Vincent, K., Arria, A. (2019). Graduate degree completion: Associations with alcohol and marijuana use before and after enrolment. Addictive Behavior Reports, Volume 9, 1- 18.

Altonji, J., Arcidiacono, P., \& Maurel, A. (2016). The Analysis of Field Choice in College and Graduate School: Determinants and Wage Effects. Handbook of Economics of Education, Vol. 5, pp. $305-396$.

Baum, S. \& Steele, P. (2017). Who Goes to Graduate School and Who Succeeds? AccessLex Institute Research Paper No. 17-01. Accessed Janaury 1, 2020 from https://papers.ssrn.com/sol3/papers.cfm ?abstract_id=28984

Civil Service Commission. Memorandum Circulars.

http://www.csc.gov.ph/2014-02-21-08-2234/2014-02-21-08-22-57.html

Commission on Higher Education. Annual Reports.

https://ched.gov.ph/statistics/

English, David and Paul D. Umbach. (2016).

"Graduate School Choice: An Examination of Individual and Institutional Effects." The Review of Higher Education, vol. 39 no. 2, p. 173-211. Project MUSE. 
Hess, F. \& Kelly, A. (2007). Learning to Lead: What Gets Taught in PrincipalPreparation Programs. Teachers College Record, 109 (1), pp. 1 - 28.

Jackson, B. \& Kelley, C. (2002). Exceptional and Innovative Programs in Educational Leadership, Educational Adminstration Quarterly, 38 (2), pp. $192-212$.

Jazaieri, H. (2017). Compassionate education from preschool to graduate school. Journal of Research in Innovative Teaching \& Learning, 11 (1), pp. $22-$ 66.

Levin, H., Belfield, C., Muennig, P., \& Rouse, C. (2007). The costs and benefits of an excellent education for all of America's children (Vol. 9). New York, NY: Teachers College Press.
Miller, A. \& Orsillo, S. (2020). Values, acceptance, and belongingness in graduate school: Perspectives from underrepresented minority students. Journal of Contextual Behavioral Sciences, 15 (1), pp. 197 - 206.

The Council of Graduate Schools. (2016). Degree Completion.

https://cgsnet.org/degree-completion

The National Center for Education Statistics (2019). Postbaccalaureate Enrollment.

https://nces.ed.gov/programs/coe/indicator_c hb.asp

Yi, D., Laux, J., Salyers, K., Kozelka, S. (2017). Personality and Graduate Academic Performance Among Counselor Education and Psychology Students. School Psychology Forum, 11 (3), pp. $105-122$. 